\title{
太極拳が精神的・身体的健康度に及ぼす効果
}

\author{
大平 雅子 ${ }^{* 1,3,4}$, 戸田 雅裕 ${ }^{* 1,2}$, 田麗 ${ }^{* 1}$, 森本 兼軍 ${ }^{* 1,3,4}$ \\ ${ }^{* 1}$ 大阪大学大学院医学系研究科・社会環境医学講座 (環境医学) \\ ${ }^{*}$ 大阪歯科大学薬理学講座 \\ ${ }^{* 3}$ 大阪大学大学院医学系研究科付属ツインリサーチセンター \\ ${ }^{* 4}$ 大阪体育大学体育学部健康・スポーッマネジメント科
}

\section{Effects of Tai Chi Exercise on Physical and Mental Health}

\author{
Masako HASEGAWA-OHIRA ${ }^{* 1}$, Masahiro TODA ${ }^{* 1,2}$, Rei DEN ${ }^{* 1}$ and Kanehisa MORIMOTO ${ }^{* 1,3,4}$ \\ ${ }^{*}$ Department of Social and Environmental Medicine, Osaka University Graduate School of Medicine \\ ${ }^{*}$ Department of Pharmacology, Osaka Dental University \\ ${ }^{* 3}$ Twin Research Center, Osaka University Graduate School of Medicine \\ ${ }^{*}$ Department of Health and Sport Management, School of Health and Sport Science, Osaka University of Health and Sport Sciences
}

\begin{abstract}
Recently, Tai Chi, which is one of the Chinese traditional martial arts, has been receiving attention. The main feature of Tai $\mathrm{Chi}$ is its flowing movements including loosening up, relaxing, and practicing meditation with slow abdominal respiration. Tai Chi is widely taken as part of health-promotion activities or rehabilitation training, and significant mental and physical effects have been reported so far. In this review report, Tai Chi was confirmed to be beneficial not only as a rehabilitation training for old people or patients with various diseases but also as an exercise for healthy people. These findings suggest the potential of Tai Chi as a complementary and alternative therapy.
\end{abstract}

Key words: Tai Chi (太極拳), rehabilitation（リハビリテーション）, physical health (身体的健康度), mental health (精神的健康度), exercise (運動)

\section{緒言}

中国の長い歴史の中で生まれた伝統武術の一つである 太極拳が，近年大きな注目を集めている(1)。太極拳と は東洋哲学の概念である「太極」（万物の根源であり, 「陰」「陽」に分化する以前の状態）思想を取り入れた武 術である。

太極拳の起源については様々な議論があるが, 通説は, 河南省温県常陽村（現・陳家溝）に強制移住させられた 陳一族に伝承されていた武術が起源であるとされてい る。底流にあるものは道教の養生法や漢方医学であり, それらの研鑽の成果として完成された。武術として継承 されてきた伝統的な太極拳は，「伝統拳」とも呼ばれる。 伝統拳はその継承者によって内容に様々な違いがあるも のの,「伝統五派」といら五つの系統に分類できる。伝統

受付 2010 年 4 月 8 日, 受理 2010 年 6 月 14 日

Reprint requests to: Kanehisa MORIMOTO

1-1 Asashirodai, Kumatori-cho, Sennan-gun, Osaka 590-0496, Japan TEL: +81(72)479-5078

E-mail: morimoto@envi.med.osaka-u.ac.jp
五派は，それ炅れ創始者あるいは代表的な継承者の姓を とって，陳，楊，呉，武，孫の名を冠する (2)。

緩やかで流れるよらなゆったりとした動作が特徵であ り, 全身の力を抜いて瞑想状態で行うのが理想とされる。 深くゆっくりとした腹式呼吸を行いながら，姿勢・気の 運用を学ぶ事で, 発勁を習得する。現在全世界で一般的 によく実施されている太極拳は簡化二十四式太極拳と呼 ばれ，複雑で難度の高い伝統的な太極拳を広く普及させ るために, 楊式を基礎として 1956 年に中国体育委員会が 制定したものである。

現在，太極拳は健康増進活動あるいはリハビリテー ション訓練の一環として広く取り入れられて打り，これ までに多くの精神的・身体的効果が報告されている。今 回数々の先行研究から太極拳に関する総合的な知見を得 たので報告する。

\section{1. 各種生体機能に対する効果}

自律神経調節機能に対する太極拳の効果については心 拍数, 拡張期 / 収縮期血圧, 平均動脈圧等の減少が認め られて扣り (3-5), 太極拳による副交感神経応答の亢進 
日衛誌 (Jpn. J. Hyg.) 第 65 巻 第 4 号 2010 年 9 月

Table 1 各種生体機能に対する太極拳運動の効果

\begin{tabular}{|c|c|c|c|c|c|}
\hline $\begin{array}{l}\text { 文献 } \\
\text { 番号 }\end{array}$ & 著者（年） & $\begin{array}{c}\text { 対象 } \\
\text { (人数・年齢) }\end{array}$ & 太極拳の実施期間 & $\begin{array}{l}\text { コントロール } \\
\text { (人数・年齢) }\end{array}$ & *太極拳による変化 \\
\hline 3 & $\begin{array}{l}\text { Ko GT, et al. } \\
(2006)\end{array}$ & $\begin{array}{l}\text { 健常女性 } \\
(20 \text { 名・40.8 } 45.9 \text { 歳 })\end{array}$ & $\begin{array}{l}10 \text { 週間 } \\
(1 \text { 時間・週 } 2 \text { 回) }\end{array}$ & - & $\begin{array}{l}\text { 拡張期血圧 }(\downarrow) \\
\text { 総コレステロール量 }(\downarrow) \\
\text { LDL コレステロール量 }(\downarrow)\end{array}$ \\
\hline 4 & $\begin{array}{l}\text { Thomas GN, et al. } \\
\text { (2005) }\end{array}$ & $\begin{array}{l}\text { 健常男女 } \\
\text { (各 } 44 \text { 名, } 20 \text { 名 } . \\
69 \pm 3.0 \text { 歳) }\end{array}$ & $\begin{array}{l}12 \text { 月 } \\
(1 \text { 時間・週 } 3 \text { 回 })\end{array}$ & $\begin{array}{l}\text { (1)筋力トレーニング群 } \\
\text { (男女計 } 65 \text { 名・ } \\
68.9 \pm 2.8 \text { 歳) } \\
\text { (2) 非介入群 } \\
\text { (男女計 } 78 \text { 名・ } \\
69.1 \pm 3.2 \text { 歳) }\end{array}$ & 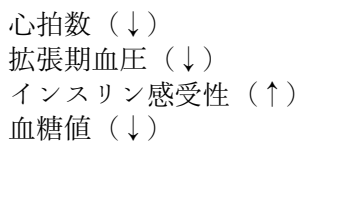 \\
\hline 5 & $\begin{array}{l}\text { Lu WA, et al. } \\
(2003)\end{array}$ & $\begin{array}{l}\text { 健常男女 } \\
\text { (太極拳経験者) } \\
\text { (各 } 9 \text { 名, } 11 \text { 名・ } \\
52.8 \pm 7.5 \text { 歳) }\end{array}$ & 40 分間 & $\begin{array}{l}\text { 太極拳未体験群 } \\
\text { (男女各 } 5 \text { 名, } 15 \text { 名・ } \\
56.3 \pm 8.5 \text { 歳) }\end{array}$ & $\begin{array}{l}\text { 心拍数 }(\downarrow) \\
\text { 拡張期 } / \text { 収縮期血压 }(\downarrow) \\
\text { 平均動脈圧 (MABP) }(\downarrow) \\
\text { 心拍圧 }(\downarrow)\end{array}$ \\
\hline 6 & $\begin{array}{l}\text { Goon JA, et al. } \\
\text { (2009) }\end{array}$ & $\begin{array}{l}\text { 健常男女 } \\
\text { (計 } 30 \text { 名・45 歳以上) }\end{array}$ & $\begin{array}{l}12 \text { ヶ月 } \\
(1 \text { 時間・週 } 2 \text { 回以上 })\end{array}$ & $\begin{array}{l}\text { 非介入群 } \\
\text { (男女計 } 30 \text { 名) }\end{array}$ & 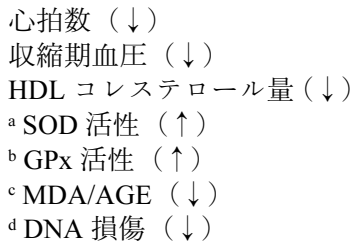 \\
\hline
\end{tabular}

*括弧内は有意な変化を示す

a SOD : スーパーオキシドディスムターゼ

${ }^{\mathrm{b}} \mathrm{GPx}:$ グルタチオンペルオキシダーゼ

${ }^{\mathrm{c}} \mathrm{MDA} / \mathrm{AGE}$ : 酸化ダメージマーカー

dコメットアッセイ法により評価

が示唆されている。また血中脂質動態についての効果も 認められており，Koら（3）は10週間の太極拳による総 コレステロール及び LDL コレステロールの減少を報告 している。加えて Thomasら（4）は健康な被験者で, 非 介入群, 筋力トレーニング群との比較に沶いて 12 ヶ月間 の太極拳によるインスリン感受性の増化を報告している。 さらに，抗酸化酵素活性の面でも太極拳の効果は注目 を集めている。Goonら（6）は太極拳介入により6ヶ月後 にはスーパーオキシドディスムターゼ (SOD), グルタチ オンペルオキシダーゼ（GPx）といった抗酸化酵素活性 が上昇し,さらに 12 ケ後には酸化ダメージのマーカー である MDA/AGE が減少するに至ることを報告してお り，これは太極拳により呼吸法が改善された為であると している。一般に, 運動時には酸化ストレス及び抗酸化 酵素活性双方の増加が認められるが $(7,8)$, 特に中等度 の運動を長期間持続して行らことにより, 抗酸化酵素活 性は高レベルで維持され, その結果運動時の酸化ストレ スに対し効果的な防御が可能になるといわれている (9)。そらした観点からも太極拳運動の持続は非常に意味 のあるものであると考えられる。

\section{2. 身体機能に対する効果}

身体機能改善に打いて，太極拳は有効な方法であると 報告した先行研究が多い。理由としては，太極拳のゆっ たりとした動きが筋力の向上や身体バランスの改善に効 果的であることが挙げられる。例えば, Maciaszekら（10）
は，骨量減少症もしくは骨粗鬆症の年配男性を被験者と して太極拳の効果を調査し，18 週間の太極拳が身体バラ ンスを有意に改善させ，転倒リスクを軽減させることを 報告している。また，同じ太極拳でも運動スピードの変 化により身体機能への効果が異なるといら報告もある。 即ちゆったりとした動きでは身体バランスを改善させる ような，また速い動きでは身体を鍛える筋力トレーニン グのような効果があり，これは太極拳のスピードにより 筋収縮様態が異なるためであると思われる(11)。一方 で，3 週間の太極拳では転倒リスクの高い高齢者の平衡 感覚や日常生活に招ける転倒回数は有意に改善されな かったといら報告もあり（12），太極拳の効果には実施期 間が影響することが示唆される。

その他にも，太極拳が触覚鋭敏性を高めるといら報告 や (13), 下肢障害者について太極拳を上半身だけで行ら ことでも肩の外旋機能及び伸展機能が上昇し，肩の柔軟 性が向上するといら報告がなされている（14）。触覚鋭敏 性の上昇については経験年数に比例するといら知見も得 られて抢り，これは太極拳を行ら際，上級者になるほど 特に指先や手の動きに注意を向けるためではないかと考 えられている(13)。

\section{3. リハビリテーション訓練としての効果}

太極拳は上述したような身体機能の改善・向上効果に より,リハビリテーション訓練の一環として広く取り入 れられている。 
日衛誌 (Jpn. J. Hyg.) 第 65 巻 第 4 号 2010 年 9 月

Table 2 身体機能に対する太極拳運動の効果

\begin{tabular}{|c|c|c|c|c|c|}
\hline $\begin{array}{l}\text { 文献 } \\
\text { 番号 }\end{array}$ & 著者（年） & 対象（人数・年齢） & 太極拳の実施期間 & コントロール（人数・年齢） & *太極拳による変化 \\
\hline 10 & $\begin{array}{l}\text { Maciaszek J, et al. } \\
(2007)\end{array}$ & 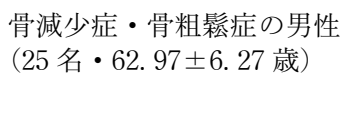 & $\begin{array}{l}18 \text { 週間 } \\
(45 \text { 分間・週 } 2 \text { 回 })\end{array}$ & $\begin{array}{l}\text { 非介入群 } \\
(\text { 骨減少症・骨粗鬆症の男性 } \\
24 \text { 名・71.06 } \\
\text { 歳 })\end{array}$ & 身体バランス（^） \\
\hline 11 & $\begin{array}{l}\text { Wu G, Ren X. } \\
(2009)\end{array}$ & 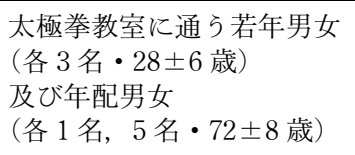 & - & - & $\begin{array}{l}\text { 大腿筋群の等尺性筋収縮 } \\
(\uparrow \text { (低速時) } \\
\text { 大腿筋群の伸張性筋収縮 } \\
(\uparrow) \text { (高速時) }\end{array}$ \\
\hline 12 & $\begin{array}{l}\text { Logghe IH, et al. } \\
(2009)\end{array}$ & $\begin{array}{l}\text { 高転倒リスク男女 } \\
\text { (各 } 42 \text { 名, } 96 \text { 名・ } \\
77.5 \pm 4.7 \text { 歳) }\end{array}$ & $\begin{array}{l}3 \text { 週間 } \\
(1 \text { 時間・週 } 2 \text { 回 })\end{array}$ & $\begin{array}{l}\text { 非介入群 } \\
\text { (高転倒リスク男女各 } 36 \text { 名, } \\
95 \text { 名・76.8 } 4.6 \text { 歳 })\end{array}$ & $\begin{array}{l}\text { 転倒回数 }(-) \\
\text { 身体バランス (-) }\end{array}$ \\
\hline 13 & $\begin{array}{l}\text { Kerr CE, et al. } \\
(2008)\end{array}$ & $\begin{array}{l}\text { 健常男女（各 } 4 \text { 名, } 10 \text { 名・ } \\
\text { 28-68 歳) }\end{array}$ & $\begin{array}{l}24 \text { 月 } \\
(40 \text { 分間・週 } 3 \text { 回 })\end{array}$ & $\begin{array}{l}\text { 非介入群 } \\
\text { (太極拳未体験男女計 } 14 \text { 名) }\end{array}$ & $\mathrm{a}$ 触覚鋭敏性（ $\uparrow ）$ \\
\hline 14 & $\begin{array}{l}\text { Cheung SY, et al. } \\
\text { (2007) }\end{array}$ & $\begin{array}{l}\text { 下肢障害者男女 } \\
\text { (各 } 4 \text { 名, } 18 \text { 名・ } \\
47.50 \pm 5.01 \text { 歳) }\end{array}$ & $\begin{array}{l}15 \text { 週間 } \\
(1 \text { 時間・週 } 2 \text { 回 })\end{array}$ & $\begin{array}{l}\text { 非介入群 } \\
\text { (下肢障害者男女各 } 10 \text { 名, } \\
7 \text { 名・45. } 59 \pm 8.45 \text { 歳) }\end{array}$ & $\begin{array}{l}\text { 右肩外旋機能 }(\uparrow) \\
\text { 右肩・左肩伸展機能 }(\uparrow)\end{array}$ \\
\hline
\end{tabular}

*括弧内は有意な変化を示す

a 右手人差し指の触二点弁別閾により評価

Table 3 リハビリテーション訓練としての太極拳運動の効果

\begin{tabular}{|c|c|c|c|c|c|}
\hline $\begin{array}{l}\text { 文献 } \\
\text { 番号 }\end{array}$ & 著者（年） & 対象（人数・年齢） & 太極拳の実施期間 & コントロール（人数・年齢） & * 太極拳による変化 \\
\hline 17 & $\begin{array}{l}\text { Shen CL, et al. } \\
(2008)\end{array}$ & $\begin{array}{l}\text { 変形性膝関節症患者男女 } \\
\text { (各 } 4 \text { 名, } 36 \text { 名・ } \\
64.4 \pm 8.3 \text { 歳 })\end{array}$ & $\begin{array}{l}6 \text { 週間 } \\
\text { (60 分間・週 } 2 \text { 回 })\end{array}$ & - & 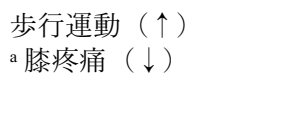 \\
\hline 18 & $\begin{array}{l}\text { Tsang T, et al. } \\
(2007)\end{array}$ & $\begin{array}{l}2 \text { 型糖尿病患者男女 } \\
\text { (各 } 2 \text { 名, } 16 \text { 名 } \cdot 66 \pm 8 \text { 歳 })\end{array}$ & $\begin{array}{l}16 \text { 週間 } \\
(45 \text { 分間・週 } 1 \text { 回 })\end{array}$ & $\begin{array}{l}\text { 柔軟体操・ストレッチ運動 } \\
\text { 実施群 } \\
(2 \text { 型糖尿病患者男女各 } 6 \text { 名, } \\
14 \text { 名・65 } 8 \text { 歳 })\end{array}$ & 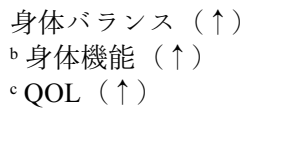 \\
\hline 19 & $\begin{array}{l}\text { LamP, et al. } \\
\text { (1999) }\end{array}$ & $\begin{array}{l}2 \text { 型糖尿病患者男女 } \\
\text { (各 } 15 \text { 名, } 13 \text { 名・ } \\
63.2 \pm 8.6 \text { 歳 })\end{array}$ & $\begin{array}{l}3 \text { ヶ月間 } \\
(1 \text { 時間・週 } 2 \text { 回 }) \\
\text { その後 } 3 \text { ヶ間 } \\
(1 \text { 時間・週 } 1 \text { 回 })\end{array}$ & $\begin{array}{l}\text { 非介入群 } \\
(2 \text { 型糖尿病患者男女各 } 9 \text { 名, } \\
16 \text { 名・ } 60.7 \pm 12.2 \text { 歳 })\end{array}$ & ${ }^{\mathrm{c}} \mathrm{QOL}(\uparrow)$ \\
\hline 20 & $\begin{array}{l}\text { LanC, et al. } \\
(2008)\end{array}$ & 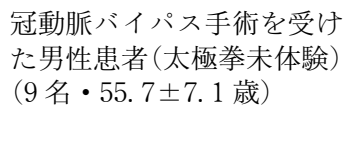 & $\begin{array}{l}1 \text { 年間 } \\
(54 \text { 分間・毎日) }\end{array}$ & $\begin{array}{l}\text { 歩行プログラム } \\
(50 \text { 分間・週 } 3 \text { 回) 実施群 } \\
\text { （冠動脈バイパス手術を受けた } \\
\text { 男性患者 } 11 \text { 名・57.2 } 57.6 \text { 歳） }\end{array}$ & $\begin{array}{l}\mathrm{d} \text { 最高酸素摂取量 } \\
\left(\mathrm{VO}_{2 \text { peak }}\right)(\uparrow) \\
\mathrm{d} \text { 換気閾值での酸素椇 } \\
\text { 取量 }\left(\mathrm{VO}_{2}\right)(\uparrow)\end{array}$ \\
\hline 21 & $\begin{array}{l}\text { Chang SY, et al. } \\
(2007)\end{array}$ & $\begin{array}{l}\text { 喘息患者児童男女 } \\
\text { (各 } 9 \text { 名, } 6 \text { 名・ } \\
9 \text { 年 } 11.6 \text { 个月 } \\
\pm 1 \text { 年 } 9.3 \text { ヶ月) }\end{array}$ & $\begin{array}{l}12 \text { 週間 } \\
(40 \text { 分間・週 } 3 \text { 回 })\end{array}$ & $\begin{array}{l}\text { 非介入群 } \\
\text { (喘息患者児童男女各 } 6 \text { 名, } \\
9 \text { 名・9年 } 3.9 \text { ケ } 1 \text { 年 } 10 \text { ケ月) }\end{array}$ & 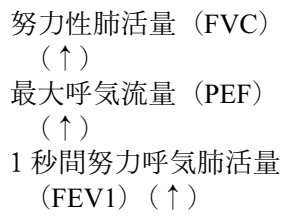 \\
\hline
\end{tabular}

*括弧内は有意な変化を示す

${ }^{a}$ Visual Analogue Scale（VAS）により評価

${ }^{\mathrm{b}}$ Six-Minute Walk Distance Test $(\mathrm{CV}=5 \%)$ により評価

${ }^{c}$ MOS 36-Item Short-Form Health Survey（SF-36）により評価

d段階的運動負荷試験（自転車エルゴメーター）により測定

例えば，変形性膝関節症や腰痛患者のリハビリテー ション訓練としての効果が調査されているが, Shen ら （15）は変形性膝関節症患者の歩行運動に扮いて，6 週間 の太極拳が非常に有効であることを報告して扣り, 歩幅, 歩調, 歩行スピードに打ける改善だけでなく, 歩行運動
時の疼痛改善も認めている。

また， 2 型糖尿病患者のリハビリテーション訓練とし て太極拳を取り入れた研究がいくつか行われて打り，身 体バランスなどの身体機能や健康関連 QOL 指標の一つ である社会生活機能に拈いて改善が認められているが, 
日衛誌 (Jpn. J. Hyg.) 第 65 巻 第 4 号 2010 年 9 月

Table 4 精神的健康度（高齢者・各種疾患患者）に対する太極拳運動の効果

\begin{tabular}{|c|c|c|c|c|c|}
\hline $\begin{array}{l}\text { 文献 } \\
\text { 番号 }\end{array}$ & 著者（年） & 対象（人数・年齢） & 太極拳の実施期間 & コントロール（人数・年齢） & * 太極拳による変化 \\
\hline 22 & $\begin{array}{l}\text { Maciaszek J, et al. } \\
(2007)\end{array}$ & $\begin{array}{l}\text { 冠動脈疾患リスクを有する } \\
\text { 男女 } \\
\text { (各 } 12 \text { 名, } 27 \text { 名・ } 45 \text { 歳以上) }\end{array}$ & $\begin{array}{l}12 \text { 週間 } \\
(60 \text { 分間・週 } 3 \text { 回 })\end{array}$ & - & $\begin{array}{l}\mathrm{a} \text { 気分状態 }(\uparrow) \\
\mathrm{b} \text { 知覚ストレス }(\downarrow)\end{array}$ \\
\hline 23 & $\begin{array}{l}\text { Lee LY, et al. } \\
(2007)\end{array}$ & $\begin{array}{l}\text { 老人ホーム居住男女 } \\
\text { (各 } 20 \text { 名, } 44 \text { 名・ } \\
83.4 \pm 7.2 \text { 歳 })\end{array}$ & $\begin{array}{l}26 \text { 週間 } \\
(60 \text { 分間・週 } 3 \text { 回 })\end{array}$ & $\begin{array}{l}\text { 非介入群 } \\
\text { (老人ホーム居住男女 } \\
\text { 各 } 25 \text { 名, } 48 \text { 名・ } 82.0 \pm 6.9 \text { 歳) }\end{array}$ & $\begin{array}{l}\mathrm{c} \text { 居住環境に対する } \\
\text { 満足度 ( } \uparrow)\end{array}$ \\
\hline 24 & $\begin{array}{l}\text { 金信敬，et al. } \\
\text { (2006) }\end{array}$ & $\begin{array}{l}\text { 太極拳実施男女 } \\
\text { (各 } 199 \text { 名, } 605 \text { 名・ } \\
71.0 \pm 4.7 \text { 歳 })\end{array}$ & - & $\begin{array}{l}\text { 同年代の健常男女 } \\
\text { (各 } 507 \text { 名, } 533 \text { 名) }\end{array}$ & ${ }^{\mathrm{d}} \mathrm{QOL}(\uparrow)$ \\
\hline 25 & $\begin{array}{l}\text { Siu AM, et al. } \\
(2007)\end{array}$ & $\begin{array}{l}\text { 慢性疾患患者 } \\
(80 \text { 名, } 18 \text { 歳以上) }\end{array}$ & $\begin{array}{l}6 \text { 週間 } \\
(2 \text { 時間・週 } 1 \text { 回 })\end{array}$ & $\begin{array}{l}\text { 慢性疾患自己管理プログラム } \\
\text { 実施群 } \\
\text { (慢性疾患患者 } 80 \text { 名, } 18 \text { 歳以上) }\end{array}$ & $\mathrm{e}$ 自己管理能力 $(\uparrow)$ \\
\hline 26 & $\begin{array}{l}\text { Dechamps A, } \\
\text { et al. (2009) }\end{array}$ & $\begin{array}{l}\mathrm{BMI} \geqq 30 \text { の肥満女性 } \\
(11 \text { 名 })\end{array}$ & $\begin{array}{l}10 \text { 週間 } \\
(2 \text { 時間・週 } 1 \text { 回 })\end{array}$ & $\begin{array}{l}\text { 運動プログラム実施群 } \\
(\mathrm{BMI} \geqq 30 \text { の肥満女性 } 10 \text { 名 })\end{array}$ & $\begin{array}{l}\mathrm{f} \text { 自己効力感 }(\uparrow) \\
\mathrm{g} \text { 抑うつ度 }(\uparrow)\end{array}$ \\
\hline 27 & $\begin{array}{l}\text { Robins JL, et al. } \\
(2006)\end{array}$ & $\begin{array}{l}\text { HIV 患者男女 } \\
\text { (各 } 35 \text { 名, } 24 \text { 名・ } \\
42.3 \pm 8.3 \text { 歳) }\end{array}$ & $\begin{array}{l}10 \text { 週間 } \\
(1 \text { 時間・週 } 1 \text { 回 })\end{array}$ & - & ${ }^{\mathrm{h}} \mathrm{QOL}(\uparrow)$ \\
\hline
\end{tabular}

*括弧内は有意な変化を示す

a Profile of Mood States（POMS）により評価

${ }^{\mathrm{b}}$ Perceived Stress Scale（PSS）により評価

c 12-item Medical Outcome Study Short Form により評価

${ }^{d}$ MOS 36-Item Short-Form Health Survey（SF-36）により評価

e 26-Items Covering Four Domains of Self-Management Behavior により評価

${ }^{\mathrm{f}}$ General Self-Efficacy Scale（GSE）により評価

${ }^{g}$ Beck Depression Inventory Short Form（BDI-SF）により評価

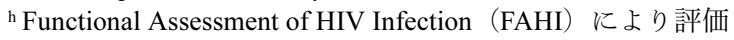

\section{Table 5 精神的健康度（健常者）に対する太極拳運動の効果}

\begin{tabular}{|c|c|c|c|c|c|}
\hline $\begin{array}{l}\text { 文献 } \\
\text { 番号 }\end{array}$ & 著者（年） & 対象（人数・年齢） & 太極拳の実施期間 & コントロール（人数・年齢） & * 太極拳による変化 \\
\hline 28 & Jin P. (1989) & $\begin{array}{l}\text { 太極拳熟練者男女 } \\
(\text { 各 } 20 \text { 名, } 13 \text { 名・ } \\
37.7 \pm 14.3 \text { 歳 })\end{array}$ & 60 分間 & $\begin{array}{l}\text { 太極拳初心者男女 } \\
\text { (各 } 16 \text { 名, } 17 \text { 名・ } \\
33.2 \pm 9.0 \text { 歳 })\end{array}$ & $\begin{array}{l}\mathrm{a} \text { 気分状態 }(\uparrow) \\
\mathrm{b} \text { 不安感 }(\downarrow) \\
\text { 唾液中コルチゾール }(\downarrow)\end{array}$ \\
\hline 29 & Jin P. (1992) & $\begin{array}{l}\text { 太極拳経験者男女 } \\
\text { (各 } 12 \text { 名・平均年齢 } 36 \text { 歳) }\end{array}$ & 60 分間 & $\begin{array}{l}\text { (1)早歩き群（男女各 } 12 \text { 名) } \\
\text { (2)瞑想群（男女各 } 12 \text { 名） } \\
\text { (3)読書群（男女各 } 12 \text { 名） }\end{array}$ & $\begin{array}{l}\mathrm{a} \text { 気分状態 }(\uparrow) \\
\mathrm{b} \text { 不安感 }(\downarrow) \\
\text { 唾液中コルチゾール }(\downarrow)\end{array}$ \\
\hline 30 & $\begin{array}{l}\text { Esch T, et al. } \\
(2007)\end{array}$ & $\begin{array}{l}\text { 大学生男女 } \\
\text { (各 } 5 \text { 名, } 4 \text { 名・ } \\
27.89 \pm 5.53 \text { 歳) }\end{array}$ & $\begin{array}{l}14 \text { 週間 } \\
(90 \text { 分間・週 } 1 \text { 回 })\end{array}$ & - & $\begin{array}{l}\text { 唾液中コルチゾール }(\downarrow) \\
\mathrm{c} \text { 知覚ストレス }(\downarrow)\end{array}$ \\
\hline 31 & $\begin{array}{l}\text { Caldwell K, et al. } \\
\text { (2009) }\end{array}$ & $\begin{array}{l}\text { 大学生男女 } \\
\text { (各 } 25 \text { 名, } 4 \text { 名) }\end{array}$ & $\begin{array}{l}15 \text { 週間 } \\
(50 \text { 分間・週 } 2 \text { 回 })\end{array}$ & $\begin{array}{l}\text { ピラティス実施群 } \\
\text { (大学生男女各 } 4 \text { 名, } 37 \text { 名) } \\
\text { 屋外レクリエーション実施群 } \\
\text { (大学生男女各 } 19 \text { 名, } 9 \text { 名) }\end{array}$ & $\begin{array}{l}\text { 自己効力感 }(\uparrow) \\
\mathrm{d} \text { 気分状態 }(\uparrow)\end{array}$ \\
\hline
\end{tabular}

*括弧内は有意な変化を示す

a Profile of Mood States（POMS）により評価

${ }^{\mathrm{b}}$ State Trait Anxiety Inventory（STAI）により評価

${ }^{c}$ Visual Analogue Scale（VAS）により評価

${ }^{\mathrm{d}}$ Four Dimensional Mood Scale により評価

血圧，インスリン感受性， $\mathrm{HbA1c}$ などの代謝調節機能及 び心血管系リスクの改善は認められていない $(16,17) 。$ その他, Lanら（18）は冠動脈バイパス手術を受けた患 者のリハビリテーション訓練として太極拳を用いた結
果，最大運動時での最高酸素拱取量（ $\mathrm{VO}_{2 \text { peak }} ）$ 及び換気 閾值での酸素摂取量（ $\mathrm{VO}_{2} ）$ の有意な増加を認め，太極 拳が心肺機能を増強し得るとしている。また，喘息患者 の子供を対象とした研究でも，12 週間の太極拳介入によ 
り, 症状の改善は認められない子のの, 努力性肺活量 $(\mathrm{FVC}), 1$ 秒間の努力呼気肺活量 (FEV1), 最大呼気流 量 (PEF) といった肺機能の改善が報告されている (19)。

\section{4. 精神的健康度に対する効果}

高齢者や各種疾患患者の精神的健康度が太極拳により 改善されるという報告が数多くなされている。なかでも 近年高龄者を対象とした太極拳の有效性を検証する研究 が大きな注目を集めて沏り，太極拳が自覚ストレスを減 少させ (20), 健康関連 QOL や自尊心を増加させること

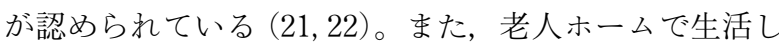
ている高齢者で，太極拳による居住環境への満足度の増 加が認められて招り (21), 精神的健康度の改善が生活の 質の向上につながる可能性も考兄られる。

また, 慢性疾患患者, 肥満患者, HIV 患者で太極拳の 効果が認められて和り, 慢性疾患患者では自己管理能力 の向上が (23), また肥満患者では体重管理プログラムに 太極拳を組み込んだ結果, 自己効力感及び抑うつ状態が 改善し，プログラム終了後も持続することが報告されて いる (24)。また，HIV 患者では太極拳による症状の抑制 に加光, QOL の改善や抑うつ度の減少が認められている (25)。

その他, 健康な被験者を対象とした研究もいくつか行 われており, Jin は太極拳による唾液中コルチゾール濃度 の減少に加兄, POMS（Profile of Mood States）に打数 「緊張一不安」「抑らつ一落込奴」怒り一敵意」「疲労」 「混乱」といったネガティブな感情の減少，及び「活気」 といったポジティブな感情の上昇を報告している $(26,27)$ 。また, 学生を対象とした調査では, 唾液中コル チゾール濃度, 精神的知覚ストレス, 抑らつ度の減少, ならびに健康感，自己効力感，睡眠の質の上昇が確認さ れている $(28,29)$ 。

\section{結語}

今回の文献学的調査で，太極拳はリハビリテーション 訓練としてだけでなく, 健常者の各種生体機能, 身体機 能, 及び精神的健康度に対しても十分に効果の期待でき ることが確認された。特に, 自己効力感, QOL, 感情な ぞの精神的健康度に対する改善効果が太極拳に特有であ ると考光られるが，太極拳の効果について Jin（26）は散 歩, 瞑想, 読書の効果と比較し, 心血管系反応から太極 拳の身体面にお和る効果が散歩と同程度であること, 未 た唾液中コルチゾール及び尿中ノルアドレナリン反応か ら精神面に与光る効果が読書と同程度であることを認 め, 即ち太極拳は散歩と読書の良さを兼敉備えたもので あるとしている。太極拳は過度の負担を伴わないゆるや かな運動であり, 運動習慣を持たない者でも無理なく取 り組むことができるのも大きな利点である。

このように太極拳は近年大いに注目を集めているもの の，その効果については科学的根拠に基づいた検証が十
分に行われていないのが現状である。しかしながら，今 回の報告からも分かるように，補足代替医療として非常 に多くの可能性を秘めているように思わ机る。先行研究 を見る限り，太極拳は運動療法の一つとして扱われてい る場合が多いが，今回得られた所見からも，今後は精神 的健康度の改善, 即ち太極拳のよりスピリチュアルな側 面に特化した効果の検証，ならびにその機序の解明が必 要である。将来的には幅広い分野に抢けるストレスマネ ジメント手法としての太極拳の役割に期待したい。

\section{文献}

(1) Sophia Delza, Taiji Chuan. Body and Mind in Harmony (Integration of Meaning and Method). Albany, NY: State University of New York press, 1985.

(2) Gu Liushen. Taijiquan Technique. Sichuan, Chinese: Shanghai Educational Publishing House, 1982.

( 3 ) Ko GT, Tsang PC, Chan HC. A 10-week Tai-Chi program improved the blood pressure, lipid profile and SF-36 scores in Hong Kong Chinese women. Med Sci Monit. 2006; 12 : CR196-CR199.

(4) Thomas GN, Hong AW, Tomlinson B, Lau E, Lam CW, Sanderson JE, Woo J. Effects of Tai Chi and resistance training on cardiovascular risk factors in elderly Chinese subjects: a 12-month longitudinal, randomized, controlled intervention study. Clin Endocrinol. 2005;63:663-669.

( 5 ) Lu WA, Kuo CD. The effect of Tai Chi Chuan on the autonomic nervous modulation in older persons. Med Sci Sports Exerc. 2003; 35:1972-1976.

( 6 ) Goon JA, Aini AH, Musalmah M, Anum MY, Nazaimoon WM, Ngah WZ. Effect of Tai Chi exercise on DNA damage, antioxidant enzymes, and oxidative stress in middle-age adults. J Phys Act Health. 2009;6:43-54.

( 7 ) Hitomi Y, Watanabe S, Kizaki T, Sakurai T, TakemasaT, Haga S, Ookawara T, Suzuki K, Ohno H. Acute exercise increases expression of extracellular superoxide dismutase in skeletal muscle and the aorta. Redox Rep. 2008;13:213216.

( 8 ) Hatao H, Oh-Ishi S, Itoh M, Leeuwenburgh C, Ohno H, Ookawara T, Kishi K, Yagyu H, Nakamura H, Matsuoka T. Effects of acute exercise on lung antioxidant enzymes in young and old rats. Mech Ageing Dev. 2006;127:384390.

（9）江口裕伸，藤原範子，大河原知水，鈴木敬一郎，谷口 直之. 酸化ストレスと健康. 生物試料分析 2009;32: 247-256.

(10) Maciaszek J, Osiński W, Szeklicki R, Stemplewski R. Effect of Tai Chi on body balance: randomized controlled trial in men with osteopenia or osteoporosis. Am J Chin Med. 2007;35:1-9.

(11) Wu G, Ren X. Speed effect of selected Tai Chi Chuan movement on leg muscle activity in young and old practitioners. Clin Biomech. 2009;24:415-421.

(12) Logghe IH, Zeeuwe PE, Verhagen AP, Wijnen-Sponselee RM, Willemsen SP, Bierma-Zeinstra SM, van Rossum E, Faber MJ, Koes BW. Lack of effect of Tai Chi Chuan in 
preventing falls in elderly people living at home: a randomized clinical trial. J Am Geriatr Soc. 2009;57:70-75.

(13) Kerr CE, Shaw JR, Wasserman RH, Chen VW, Kanojia A, Bayer T, Kelley JM. Tactile acuity in experienced Tai Chi practitioners: evidence for use dependent plasticity as an effect of sensory-attentional training. Exp Brain Res. $2008 ; 188: 317-322$.

(14) Cheung SY, Tsai E, Fung L, Ng J. Physical benefits of Tai Chi Chuan for individuals with lower limb disabilities. Occup Ther Int. 2007;14:1-10.

(15) Shen CL, James CR, Chyu MC, Bixby WR, Brismée JM, Zumwalt MA, Poklikuha G. Effects of Tai Chi on gait kinematics, physical function, and pain in elderly with knee osteoarthritis—a pilot study. Am J Chin Med. 2008;36: 219-232.

(16) Tsang T, Orr R, Lam P, Comino EJ, Singh MF. Health benefits of Tai Chi for older patients with type 2 diabetes: the "Move It For Diabetes study" $\mathrm{A}$ randomized controlled trial. Clin Interv Aging. 2007;2:429-439.

(17) Lam P, Dennis SM, Diamond TH, Zwar N. Improving glycaemic and BP control in type 2 diabetes. The effectiveness of tai chi. Aust Fam Physician. 2008;37:884-887.

(18) Lan C, Chen SY, Lai JS, Wong MK. The effect of Tai Chi on cardiorespiratory function in patients with coronary artery bypasses surgery. Med Sci Sports Exerc. 1999;31: 634-638.

(19) Chang YF, Yang YH, Chen CC, Chiang BL. Tai Chi Chuan training improves the pulmonary function of asthmatic children. J Microbiol Immunol Infect. 2008;41:88-95.

(20) Taylor Piliae RE, Haskell WL, Waters CM, Froelicher ES. Change in perceived psychosocial status following a 12week Tai Chi exercise programme. J Adv Nurs. 2006;54: 313-329.
(21) Lee LY, Lee DT, Woo J. Effect of Tai Chi on state selfesteem and health-related quality of life in older Chinese residential care home residents. J Clin Nurs. 2007;16: 1580-1582.

（22）金 信敬，鳥羽研二，折茂 肇．太極拳運動実施高齢 者の健康関連 QOL一同年代国民標準值との比較一. 日老医誌 2007; 44:339-344.

(23) Siu AM, Chan CC, Poon PK, Chui DY, Chan SC. Evaluation of the chronic disease self-management program in a Chinese population. Patient Educ Couns. 2007;65:42-50

(24) Dechamps A, Gatta B, Bourdel-Marchasson I, Tabarin A, Roger P. Pilot study of a 10-week multidisciplinary Tai Chi intervention in sedentary obese women. Clin J Sport Med. $2009 ; 19: 49-53$.

(25) Robins JL, McCain NL, Gray DP, Elswick RK Jr, Walter $\mathrm{JM}, \mathrm{McDade}$ E. Research on psychoneuroimmunology: tai chi as a stress management approach for individuals with HIV disease. Appl Nurs Res. 2006;19:2-9.

(26) Jin P. Changes in heart rate, noradrenaline, cortisol and mood during Tai Chi. J Psychosom Res. 1989;33:197206.

(27) Jin P. Efficacy of Tai Chi, brisk walking, meditation, and reading in reducing mental and emotional stress. J Psychosom Res. 1992;36:361-370.

(28) Esch T, Duckstein J, Welke J, Braun V. Mind/body techniques for physiological and psychological stress reduction: stress management via Tai Chi training - a pilot study. Med Sci Monit. 2007;13:CR488-CR497.

(29) Caldwell K, Harrison M, Adams M, Triplett NT. Effect of Pilates and taiji quan training on self-efficacy, sleep quality, mood, and physical performance of college students. J Bodyw Mov Ther. 2009;13:155-163. 